\title{
The Nexus between the Austrian Forestry Sector and the Sustainable Development Goals: A Review of the Interlinkages
}

\author{
Reneema Hazarika ${ }^{1, *}$ and Robert Jandl ${ }^{2}$ D \\ 1 Department of Forest Growth and Silviculture, Austrian Research Centre for Forests, \\ BFW Seckendorff-Gudent-Weg 8, 1130 Vienna, Austria \\ 2 Special Unit of Climate Impact Research Coordination, Austrian Research Centre for Forests, \\ BFW Seckendorff-Gudent-Weg 8, 1130 Vienna, Austria; robert.jandl@bfw.gv.at \\ * Correspondence: reneema.hazarika@bfw.gv.at
}

Received: 31 January 2019; Accepted: 21 February 2019; Published: 26 February 2019

\begin{abstract}
Since the inception of the Sustainable Development Goals (SDGs) in 2015, there has been much conceptual progress on the linkages across the 17 goals and their 169 targets. While this kind of conceptualization is an essential first step, action must now move towards systematic policy design, implementation, and multi-stakeholder collaborations that can translate such understanding into concrete results. This study is a reality check of such quasi-political global development agendas by the United Nations and its implications on Austrian forestry. Although forestry is not a goal in itself, forests as an element have been included under SDG15 (Life on Land). In this study, the linkages of forestry with potential synergies or trade-offs within and between the SDGs have been assessed through a literature survey and complemented with the perception of opinion leaders across the Austrian forestry sector on the same. The insights about awareness, design, implementation, and the necessity of mainstreaming the SDGs into the policy structure of Austria were reviewed. Besides facilitating the goals of sustainable forest management (SFM) in Austria, the SDG15 is not only strongly related to, but is likely to aid, the achievement of other SDGs, such as human health (SDG3), provision of clean water (SDG6), affordable \& clean energy (SDG7), and climate action (SDG13). The opinion leaders perceive the SDGs as well-placed but broad. Some this broadness is a positive aspect of the SDGs. On the other hand, the 15-year (2015-2030) tenure of the SDGs is perceived to be inadequate to match the temporal scale of forest development. Apparently, the success of the SDGs will strictly depend upon coordination, governance, and most importantly, awareness among all stakeholders. Therefore, in addition to "leaving no one behind", the SDGs must evidently provide incentives benefitting everybody.
\end{abstract}

Keywords: sustainable development goals; Austrian forest; forestry; sustainability

\section{Introduction}

The United Nations' (UN) Sustainable Development Goals (SDGs), also referred to as Agenda 2030 [1], which came into effect from January 2016, is an overarching blueprint for action to end poverty, protect the planet, and ensure overall peace and prosperity. Comprising 17 goals and 169 targets, with tenure until 2030, the SDGs include themes such as climate change, economic inequality, innovation, sustainable consumption, and peace and justice, among other priorities [2]. With planned targets, indicators, and wide international consensus, the SDGs come across as a successful process for sustainable development globally. The goals are mostly interconnected and are seen as interdependent on each other [3], which is not only key to their overall success but may also pose certain challenges in their way of fulfillment. 
Briefly, the SDGs combine (i) a human security agenda with basic needs (SDG1 end poverty, SDG2 zero hunger, SDG3 health \& wellbeing), (ii) universal objectives (SDG4 education, SDG5 gender equality, SDG10 reduced inequality), (iii) social development (SDG8 economic growth, SDG9 infrastructure \& innovation, SDG11 sustainable cities), (iv) a planetary boundary agenda which includes confining factors (SDG13 climate change, SDG14 marine ecosystems, SDG15 terrestrial ecosystems) and particular sensitive factors (SDG6 water quality, SDG7 energy supply, SDG12 consumption patterns), and (v) framing meta targets like peace and global partnership (SDG17) [4]. The SDGs much like the Millennium Development Goals (MDGs), realized the importance of ensuring the sustainability of the life support systems on Earth. But, unlike the MDGs of 2000 [5], the SDGs envision an "inclusive world" that is not restricted to developing countries alone, and therefore it is no lesser than a social movement where the goals and targets will likely stimulate action in areas of critical importance for humanity and the planet over the next decade [3].

Forests, as important earth support-systems, play a major role in sustaining food security, regulating the water resources, and mitigating climate change, besides providing an economic aspect with a wide range of other ecosystem services [6-11].

Sustainable management of forests and conservation of terrestrial ecosystems with their biodiversity has been explicitly recognized within SDG15 [3,12]. SDG15 aims to "protect, restore and promote sustainable use of terrestrial ecosystems, sustainably manage forests, combat desertification, and halt/reverse land degradation and halt biodiversity loss" [1]. This goal includes 12 targets, each of which can be assessed by a set of indicators (see Table A1, Targets and Indicators).

Utilization of European forest dates back to more than 7000 years, giving evidence on early Holocene forests [13-15]. But it was in the latter part of 1713 \{when the term sustainable forest management (SFM) officially was mentioned in the "Sylvicultura Oeconomica" authored by Hans Carl von Carlowitz, which finally ushered in an era of formal forestry education in Europe [16]. The concept of SFM in the early 1990s included the definition of what can be expected from forests and wooded land [17] and was restricted to aspects of growing forests for the production of timber alone. Today, SFM has moved from its historic goal of sustainable timber production to simultaneously provide multiple ecosystem services [18], playing a crucial role in the steady supply of economic and ecological benefits [7]. Target 154 of SDG15 specifically prescribes the sustainable management of mountain forests, which form the major terrestrial ecosystems in countries such as Austria [12]. Austria has a long tradition of SFM, the foundation of which is a complex pan-European concept that has been developed over time [19]. The indicators used in this Pan-European concept were adapted to Austrian conditions by taking into account aspects such as the dominance of small-scale forest land holdings and highly differentiated biogeography [20]. The SDGs have been recently discussed in light of their potential of realizing the goals of SFM, biodiversity conservation, climate change mitigation, and bioeconomy [3,12,21-25]. However, in the context of forestry, major knowledge gaps still exist in our understanding of the interactions between goals and targets of Agenda 2030 [3,12].

In this article, we consider the viewpoint of the forestry sector and analyze the interlinkages of SDG15 with SFM, along with other relevant goals of Agenda 2030. The objective is to examine whether the SDGs amend or further strengthen the currently implemented SFM concepts in Austria. Our focus is to review the synergies and the trade-offs within and between the SDGs in the context of the Austrian forestry sector. We further complement this review by incorporating the perceptions of forestry and its alignment to the SDGs among the key opinion leaders from the Austrian forestry sector such as forestry institutions, policy-making bodies, research institutes, and international NGOs and stakeholder platforms.

The narrative of this article, presented in the results and discussion, is divided into two parts. The first part is an overview, and the second is the perception of opinion leaders. The overview begins with a brief scope of sustainability and SFM along with forestry policies and processes of Europe and Austria in concurrence with global goals. This is followed by synthesis of the interlinkages of SDG15, moving over to sustainability as a concept in the design of the forestry business and ending with the 
impact of sectoral view of forestry. In the perceptions section, we examine the views on the SDGs by important opinion leaders in the Austrian forestry sector to draw the conclusion.

\section{Methods}

To understand the interactions of the SDG15 with other goals, firstly we reviewed relevant literature, including scholarly articles and grey literature focusing mainly on the SDGs in relation to sustainability and Austrian forests. Furthermore, the literature review is complemented with perceptions of the opinion leaders collected through personal interviews with a structured questionnaire (Table A2 in Annex). The participants for the interview were chosen based on their role and experience within the research, practice, and policy framing bodies within the Austrian forestry sector. To analyze these perceptions, we used the ethos of grounded theory [26], which aims at developing a substantive formal theory, and thus a means of explaining social processes. Additionally, we used Symbolic Interactionism [27] to interpret the respondents' perceptions in face-to-face interviews. This refers to the patterns of communication and interpretation between people, mainly with a person of authority. Both the verbal and nonverbal responses that a listener then transcribes are similarly constructed in expectation of how the original speaker will actually react without pretense [28]. The purpose of this is to bring forth a theoretical basis that could reveal the different perspectives and the backgrounds of this understanding.

\section{Results and Discussions}

\subsection{Sustainable Forest Management (SFM) and Austrian Forests}

Austria comprises $67 \%$ of the total territory complying with the EU definition of mountainous area and about half of the country's landmass is covered by forest $[19,29]$. The Austrian forest cover has continuously increased in recent decades and is presently at $47.1 \%$ [29] and encompasses an important part of Austrian culture, livelihood, biogeography, and economy. The concept of SFM is deeply ingrained in forest owners of the country. A positive balance between the annual increment in wood stocks $\left(30\right.$ million $\left.\mathrm{m}^{3}\right)$ compared to its utilization $\left(26\right.$ million $\left.\mathrm{m}^{3}\right)$, its high share of forests with conservation and protective function $(21.5 \%)$, and its focus on multifunctionality demonstrates the aspects of sustainability in the Austrian forestry sector [30]. The value chain from forestry to timber processing plays an important role in the economic development of the forest land-holding communities. Particularly in mountain areas, forests provide a number of ecosystem services that are essential for human well-being throughout. According to the Austrian Ministry of Sustainability and Tourism, BMNT [31], the country could become a relevant model for SFM, and the environmental standards of the country's export-oriented timber industry are evidence of its international commitment to the preservation of forests.

Austrian enterprises and institutions from the forest and timber industry are looking to expand their activities abroad [32], yet, for the purpose of sustainability and global responsibility, the Austrian Forest Program [32] demands that these enterprises and institutions must meet proper environmental and social standards in all activities and exports. The country's forestry sector has extensive expertise in forest-related research, education, and practice [25]. Many of these enterprises are technological pioneers in the fields of environmentally-compatible technology, at both the local and international level. These technologies are presented all over the world as good practice examples within the framework of the export initiative "Forst-Holz", or "Forest-Wood" [33]. However, forests in Austria, just like everywhere else, are vulnerable to global climate change [34-38].

Therefore, in the future, maintaining the sustainability of Austria's forest-based bioeconomy will be a challenge given the likelihood of drastic changes in its production potential and risks under climate change [7]. 


\subsection{Relevant Policies and Processes}

Since 1990, the Pan-European Ministerial process for the protection of forests, aka Forest Europe, comprised of 44 states, addresses issues and challenges in forest and forestry at a high political level and establishes common solutions [39]. This cooperation has adopted a number of resolutions like the Helsinki resolutions in 1993 [40] dealing with selective measures for the conservation and sustainable management of forests. The Strasbourg Resolution S4 of 1990 [41] lays the modalities for the member states of the European Union to mobilize their common resources for building concrete policies for mountain ecosystems. In Europe, countries like Austria with extended mountain regions form a part of the international framework of Forest Europe 2011 [39], which is dedicated to cross-border strategic cooperation between regions dominated by mountain-forests. The Forest Europe process also lays down 34 quantitative indicators \& 11 qualitative indicators for SFM [39]. Most of these indicators are observed to have a direct linkage with SDG15. These criteria have implicit links with other SDGs, such as maintenance of the socio-economic functions of forests with SDG3 (health and wellbeing) and forest production with SDG9 (clean energy) via the production of energy from woody biomass (Table 1).

Table 1. Criteria for sustainable forest management (SFM) from Forest Europe (2016) [19] and their linkages with the Sustainable Development Goals (SDGs) marked in gray.

\begin{tabular}{|c|c|c|c|c|}
\hline \multirow[b]{2}{*}{ Forest Europe 2012 Criteria of SFM } & \multicolumn{4}{|c|}{ Linkages with Relevant SDGs } \\
\hline & 3 gaODWEAIIM & 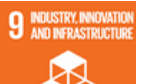 & 13 action & 15 些 \\
\hline $\begin{array}{l}1 \text { Maintenance and Enhancement of Forests and } \\
\text { their Contribution to the Carbon Cycle }\end{array}$ & & & & \\
\hline $\begin{array}{l}2 \text { Maintenance of Forest Ecosystem Health and } \\
\text { Vitality }\end{array}$ & & & & \\
\hline $\begin{array}{l}3 \text { Maintenance and Encouragement of Productive } \\
\text { Functions of Forests }\end{array}$ & & & & \\
\hline $\begin{array}{l}4 \text { Maintenance, Conservation, and Enhancement of } \\
\text { Biological Diversity in Forests }\end{array}$ & & & & \\
\hline $\begin{array}{l}5 \text { Maintenance and Enhancement of Protective } \\
\text { Functions in Forest management }\end{array}$ & & & & \\
\hline $\begin{array}{l}6 \text { Maintenance of other socio-economic functions } \\
\text { and conditions }\end{array}$ & & & & \\
\hline
\end{tabular}

The six criteria of the SFM from Forest Europe (2016) [19] are linked to multiple SDGs demonstrating the holistic approach of the SDGs in addressing vital issues of sustainability such as health, climate change, industrial innovation and infrastructure (Table 1). The majority of the SFM criteria are strongly linked to SDG15 and SDG13. The Austrian Forest Act (1975) [42] amended in 2002 [32] deals with SFM with the four important principles of production, protection, environment, and recreation. Supplementing these sub-national and national policies are the various trans-national policies and instruments, such as the Alpine convention (1991) [43] which aims at environmentally compatible use of the entire alpine region in an economically, ecologically, and socially-balanced way through its Mountain-Forest Protocol [32].

The majority of Austria's national and trans-national policies are inexplicitly linked to the SDGs, especially the SDG15 for biodiversity and forests. Besides a number of national strategies on forests, climate, and energy, under the umbrella of the Austrian EU-presidency, the "FTP Vision 2040 of the European Forest-based Sector" was launched in 2018 in Austria [44]. This is another important commitment for the European Forestry-based Sector. With 10 targets (Table 2) to be fulfilled by 2040, it shows that the forest-based sector is a leading actor and an enabler of a circular bio-economy. These strategies are in sync with some of the SDGs without even following the latter in its framework. 
The SDGs 3, 7, 8, 9, 12, 13, and 15 are observed to have been in practice always within SFM policies and processes throughout Europe (Table 2).

Table 2. The synergies between the European forestry-based sector (Vision 2040) targets and their relevant SDGs [44].

\begin{tabular}{|c|c|c|c|c|c|c|c|}
\hline \multirow[b]{2}{*}{ TARGETS-VISION 2040} & \multicolumn{7}{|c|}{ Relevant SDGs } \\
\hline & 3 & 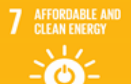 & 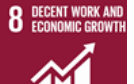 & 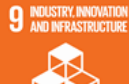 & 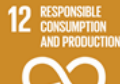 & 13 achour & 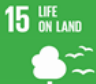 \\
\hline $\begin{array}{l}\text { 1.SFM, biodiversity and } \\
\text { resilience to climate change }\end{array}$ & & & & & & & \\
\hline $\begin{array}{l}\text { 2. Sustainable wood } \\
\text { production and mobilization }\end{array}$ & & & & & & & \\
\hline $\begin{array}{l}\text { 3. Added value from } \\
\text { nonwood ecosystem services }\end{array}$ & & & & & & & \\
\hline 4. Zero waste circular society & & & & & & & \\
\hline $\begin{array}{l}\text { 5. Efficient use of natural } \\
\text { resources }\end{array}$ & & & & & & & \\
\hline $\begin{array}{l}\text { 6. Diversification of } \\
\text { production technologies }\end{array}$ & & & & & & & \\
\hline $\begin{array}{l}\text { 7. Safe jobs and linkages of } \\
\text { rural and urban regions }\end{array}$ & & & & & & & \\
\hline $\begin{array}{l}\text { 8. Renewable building } \\
\text { materials for healthier living }\end{array}$ & & & & & & & \\
\hline $\begin{array}{l}\text { 9. Fiber-based products and } \\
80 \% \text { lower } \mathrm{CO}_{2} \text { emissions }\end{array}$ & & & & & & & \\
\hline 10. Renewable energy & & & & & & & \\
\hline
\end{tabular}

Therefore, SDGs 9, 12, and 13 found emphasis in the Austrian Forest policies and SDGs like 3, 7, 8 , and 15 are part of the existing policies. With upcoming frameworks and processes like Vision-2040, more sectors are being linked and addressed under the Forest umbrella (Tables 1 and 2).

\subsection{Interlinkage and Trade-Offs between SDG15 and Other Goals}

Although forests are not center-stage in SDG15 (Life on Land), two of the twelve targets, 15.a and 15.b, explicitly refer to forestry [45]. Target 15.a mentions financial resources to conserve and sustainably use biodiversity and ecosystems, and target 15.b, is about financing SFM. Under SDG15, Austria can contribute to raising well-managed and healthy forests, not only for revenue-generating timber products but for overall human wellbeing, thus connecting SDG15 to SDG3 (good health and well being) and SDG8 (decent work and economic growth).

Target 15.4 emphasizes specifically the conservation of mountain ecosystems [12], including biodiversity, and their role in the provision of goods and services. Biodiversity might be under pressure as soon as forest management is intensified for the sake of management concepts. The overlap of these targets is proving to be one of the demeaning factors in the full-fledged implementation of this goal. But in Austria, these impacts are yet to be analyzed.

Target 15.5 aims at reducing the degradation of natural habitats of animals, which will positively impact the protection of forests and mountain areas. Target 15.6 directs the attention to the utilization of genetic resources [46] which is one important criterion in SFM. Genetically modified organisms (GMO) are still a controversial topic. The socio-political and scientific dispute between developed nations including Europe has already spilled over to international regulation of GMOs and highly influenced the regulation and decision-making [47]. The target 15. $a$ emphasizes the need for mobilizing finances for the conservation of biodiversity and ecosystems. However, this can be a conflict of interest or at 
least low value for money, when at the same time there are undermining and contradictory policies in other areas such as agriculture, transport and infrastructure, mining, and economic development.

SDG13 (Climate Action) a central issue in forestry. Forests are mitigating climate change, and are also adversely affected, leading to the need for adaptive management in order to cope with climate change [48].

SDG4 focuses on ensuring "inclusive and equitable quality education and promote lifelong learning opportunities for all" [49]. There is an intrinsic connection between the management of forests and education. If education is awareness and knowledge of know-how, SFM needs that expertise. This has synergy with target 4.7 which mentions "education for sustainable development and global citizenship" [1]. There are forestry training centers of the Federal forest and the Austrian Research Centre for Forests (BFW) aiming at life-long learning in SFM and legislation on forests. The University of Natural Resources and Life Sciences (BOKU), Vienna, offers academic training in forestry, wood technology, and management of natural hazards. In addition, Austrian research institutes and universities conduct research and have externally funded projects which indirectly or directly contribute to almost all the SDGs [45].

SDG6 emphasizes "clean water". Forest productivity depends on the availability of water and nutrient supply, and in turn, regulates the provision of a clean and sustainable water supply [50,51]. Mountains are considered as the water towers of Europe [51]. Water flowing in hill streams is the basis of life in the valleys. The mountain forests and water are intrinsically related. In the context of target 6.6 , to mitigate water scarcity, protecting the water-related ecosystem (i.e, forests and mountains) will be very essential. Target $6 . b$ is widely seen in central Europe with communities working together for water management.

Forests have a major role in providing clean and affordable energy and are an extremely carbon-efficient land use system [52], thus supporting SDG7 . Mostly as a byproduct of timber production, bioenergy from woody biomass plays a big role in the supply of renewable energy. With a more than $58.6 \%$ share in the renewable sector, biomass is the most important source of renewable energy in Austria [53]. Despite a growing energy use of biomass, the stocks of wood are continuously increasing in Austria, balancing the demand and supply of biomass for renewable

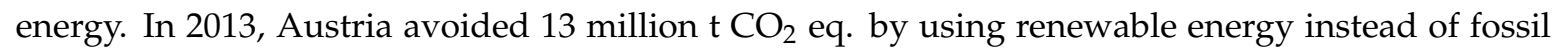
energy [53]. Roughly half of this emissions reduction is due to using renewable energy for a source of domestic and industrial heating [53]. The traditional fuelwood production in rural areas is increasingly adopted by small-holder foresters in central Europe. As the forest area in Europe is expanding [32], there could be pressure to convert the forests to renewable energy plantations, which might even lead to a greater area in tree plantations for energy production [54].

Target 8.9 of SDG8 stipulates that by 2030, policies to promote sustainable tourism that creates green jobs and promotes local culture and products should be implemented. According to 2013 figures, environmental economy or 'eco-industry' companies employ over 4.2 million people, with a turnover of more than EUR 700 billion [55]. Tourism generates revenue and is an important source of alternative livelihood for many rural communities which were traditionally governed by forestry and agriculture. It is one of the key drivers of sustainable development as it benefits economic growth and elevates general living standards as well as protects the environment.

SDG9 focuses on resilient infrastructure links between natural hazard prevention and infrastructure protection and puts forestry on the agenda, particularly in mountain areas. Accessibility to mountain forests through well-planned roads is encouraging the new generation of foresters to take up management in a better way. Also, this will give the country's tourism a high impetus. Targets 8.2 and 11.a of SDG8 can be seen as part of the Rural Development Agenda. The topic is currently relevant for central Europe but may be of increasing relevance in other regions in the future [31].

The focus of SDG11 is sustainable cities and reviews affordable and resilience housing and can be linked indirectly to timber production in forests under SDG15. Climate change, disaster resilience, and 
protection of natural heritage also form part of this goal showing a relation to SDG13. One cannot deny the potential of forests and green spaces for enhancing human health, SDG 3. The Forest Europe Work Programme 2016-2020 specifically includes a topic emphasizing the benefits and impacts of forests on human health and wellbeing [56]. Fostering synergies between cities and forest sectors can enable the creation of new businesses in forestry and promote sustainable production.

SDG12 is about responsible consumption and production, but in relation to the forestry sector, it might act as a misnomer. The importing/exporting of timber and other wood products across continents to fulfill nationwide demand cannot be called sustainable. Also, the energy used for this transportation is not sustainable and will increase the carbon footprint, impeding the targets under SDG13, climate action. Therefore, it requires a global scale policy analysis to decide on agreeable options. One of the targets of SDG12 is to achieve the sustainable management and efficient use of natural resources by 2030 and to significantly reduce their release into the air, water, and soil in order to minimize their adverse impacts on human health and the environment.

Lastly, SDG17 promotes the development, transfer, dissemination, and diffusion of environmentally-sound technologies to developing countries on favorable terms. According to Kroll (2015) [57], Austria was one of the countries, leading with target 17.2, i.e., the capacity to monitor the SDGs.

The above-mentioned SDGs and their targets are more relevant in the present Austrian context. The nature of such interactions between the SDGs may be indivisible, enabling, reinforcing etc. (Table 3 ). The interactions are focused on the Austrian Forest sector and therefore may differ slightly from the interactions of SDG15 with forests of other parts of the world, such as in the tropical countries where SDG15 is strongly related to hunger and poverty (SDG1 and SDG2 respectively).

Table 3. The interaction of SDG15 with other SDGs modified from Nisson et al. (2016) [58].

\begin{tabular}{|c|c|c|c|}
\hline $\begin{array}{l}\text { Interacting } \\
\text { Goals }\end{array}$ & $\begin{array}{l}\text { Interaction } \\
\text { Type }\end{array}$ & Explanation & Example \\
\hline $\begin{array}{l}\text { SDG13, } \\
\text { SDG6 }\end{array}$ & Indivisible & $\begin{array}{l}\text { Inextricably linked to the } \\
\text { achievement of another goal. }\end{array}$ & $\begin{array}{l}\text { Sustainable forestry cannot be achieved without policies } \\
\text { for adapting and mitigation of climate change } \\
\text { Forest protecting and sustainable is intrinsically related to } \\
\text { regulating clean water sources }\end{array}$ \\
\hline $\begin{array}{l}\text { SDG3, } \\
\text { SDG11 }\end{array}$ & Reinforcing & $\begin{array}{l}\text { Aids the achievement of } \\
\text { another goal. }\end{array}$ & $\begin{array}{l}\text { Sustainable forestry and protecting productivity and } \\
\text { sustainability of forests aids in better human health and } \\
\text { wellbeing (SDG3), } \\
\text { Urban forests have an intrinsic value for sustaining green } \\
\text { space and living conditions of cities }\end{array}$ \\
\hline $\begin{array}{l}\text { SDG13, } \\
\text { SDG9, } \\
\text { SDG7 }\end{array}$ & Enabling & $\begin{array}{l}\text { Creates conditions that } \\
\text { further another goal. }\end{array}$ & $\begin{array}{l}\text { Protecting the forests and green cover enhances carbon } \\
\text { stocks and sequestration, which indirectly mitigates } \\
\text { climate change. } \\
\text { Innovations for genetic variations and adaptation under } \\
\text { climate change and increasing health of forests. } \\
\text { Innovations in Forestry based industrial sector can enable } \\
\text { viable conditions for sustainable production for example } \\
\text { cleaner bioenergy }\end{array}$ \\
\hline SDG6 & Consistent & $\begin{array}{l}\text { Clean- water availability } \\
\text { management is symbiotic } \\
\text { with forestry }\end{array}$ & $\begin{array}{l}\text { Sustainable forests are not likely to negatively impact any } \\
\text { of the other SDGs }\end{array}$ \\
\hline None & Constraining & $\begin{array}{l}\text { Limits options on another } \\
\text { goal. }\end{array}$ & $\begin{array}{l}\text { Sustainable forests are not likely to negatively impact any } \\
\text { of the other SDGs }\end{array}$ \\
\hline None & Counteracting & Clashes with another goal. & $\begin{array}{l}\text { Sustainable forest management might seem to impact } \\
\text { sustainable agriculture and food security (SDG2) in other } \\
\text { countries but in the context of Austria, it is not likely to } \\
\text { have any negatively impact. }\end{array}$ \\
\hline None & Canceling & $\begin{array}{l}\text { Makes it impossible to reach } \\
\text { another goal. }\end{array}$ & $\begin{array}{l}\text { Sustainable forests are not likely to negatively impact any } \\
\text { of the other SDGs }\end{array}$ \\
\hline
\end{tabular}




\subsection{SDGs and Austrian Forestry Business}

Regarding the investments and profit in the forestry sector, whether it is from the timber industry or recreation and esthetics or clean energy, everything contributing to the SDGs has repercussions on society and business in particular. The Austrian forestry sector with around 145,000 forest landowners plays an important part in the economy [23], especially in rural areas. Austrian forest areas are expecting a 7\% increase in removals of timber from for 2017, a rate which remained stable throughout 2018. Some 0.3 million individuals obtain their main source of income from the forestry industry in Austria, which achieves an annual production value of about $€ 12$ billion in more than 172,000 enterprises [59]. Forestry businesses in Austria comprised of the wood, paper, and board industries involving $80 \%$ of private forest owners play an important role in the overall economy of the country [32]. Timber is a stable element of Austria's forest economy; in fact, with its export surplus of almost 3.7 billion Euros, the forest and timber industry is, besides tourism, Austria's most important foreign-exchange earner [59]. In 2013, the forestry sector accounted for only about $2.5 \%$ of the GDP; in absolute terms, the gross value added amounted to $€ 8$ billion. However, with a foreign trade surplus of $€ 4.16$ billion, the value-added chain of forest timber-paper is one of the most important items of Austria's foreign trade exports [60].

With forestry enterprises utilizing new opportunities for value-added services from fibers and other wood components, the economy of the sector is predicted to rise in value [61]. The country enjoys this favorable trend for the wood processing industry as well. However, this assessment is under pressure, especially in some parts of Austria where damage due to bark beetles has risen dramatically since 2017 [62] and the prices of roundwood have dropped. According to the Austrian Market Report of 2017, the paper industry expects some increase in supply for the year 2018 [59]. The forestry sector is constantly changing to adapt to new needs. Although the commercial forestry sector of Austria has a strong component of sustainability and with the SDGs in sight, businesses will need to rethink their strategies and change behaviors to demonstrate their contributions to the global movement.

Forestry policies often address issues related to economic development, infrastructure, and environment. While there are interdependencies between sectors under SDGs, decision and policy making for each sector generally take place separately. The downside of this "silo" approach is ineffective resource allocations and counterproductive policies [63].

\subsection{Perceptions of the SDGs Within the Austrian Forestry Sector}

The above overview compiled through the general literature survey is supplemented by perceptions collected from 30 opinion leaders across the Austrian forestry sector, each of them representing a working group ranging from approximately 5 individuals (in research institutes) up to more than 100 (in the forestry institutes, non-profit, and the ministry units). The names of the respondents are withheld in the text for privacy purpose. The words/phrases emphasized on by the respondents during the interviews are highlighted by quotation marks.

The perceptions on the synergies of the associations of the different SDGs with forestry slightly differed between the respondents from different backgrounds. The similarities and differences are discussed in the following sections. Frequent expressions of the opinion leaders are presented within quotations. "Useful and not so useful SDGs" and their level of association with forests: According to the respondents, SDGs 13, 3, 6, 7, 9, and 13, are directly associated with SDG15's forestry sector, and SDGs $2,8,11,12$, and 17 are not as closely associated with their immediate work, whereas SDGs 1, 4, 5, 10, and 14 are distantly related with almost no impact on their work (Figure 1).

"SDGs are political in nature." Almost all of the respondents were positive about the "very political nature" of Agenda 2030. Notable was their expression which portrayed the way the different groups of academics, non-profits, and the policy-making bodies perceived the SDGs. In Austria, it is observed that except for the policy-making bodies, there seemed to be a high rate of disinterest in the SDGs among private foresters and researchers with regards to familiarizing themselves with Agenda 2030, which they deem to be a metapolitical process. "As a small-scale forester I think SDG framework 
is not relevant for me" or "As a researcher working on temperate forests, I don't think I will use the SDGs for my work" and "It's more at the international level, rooted in a political process at the UN level" are some of the responses noted during the interviews. Therefore, a kind of reluctance has been observed among forestry practitioners and research bodies to delve into the SDG milieu since it is "very politically inclined." An important reason for this seems to be the lack of proper awareness and the absence of incentives for the implementation of the SDGs in personal or development projects. The political bodies, on the other hand, seem to be assured that the political nature of the development goals is very appropriate in the sense that political entities like the SDGs require a top-down approach for integration into the masses. This will not be possible without political will.

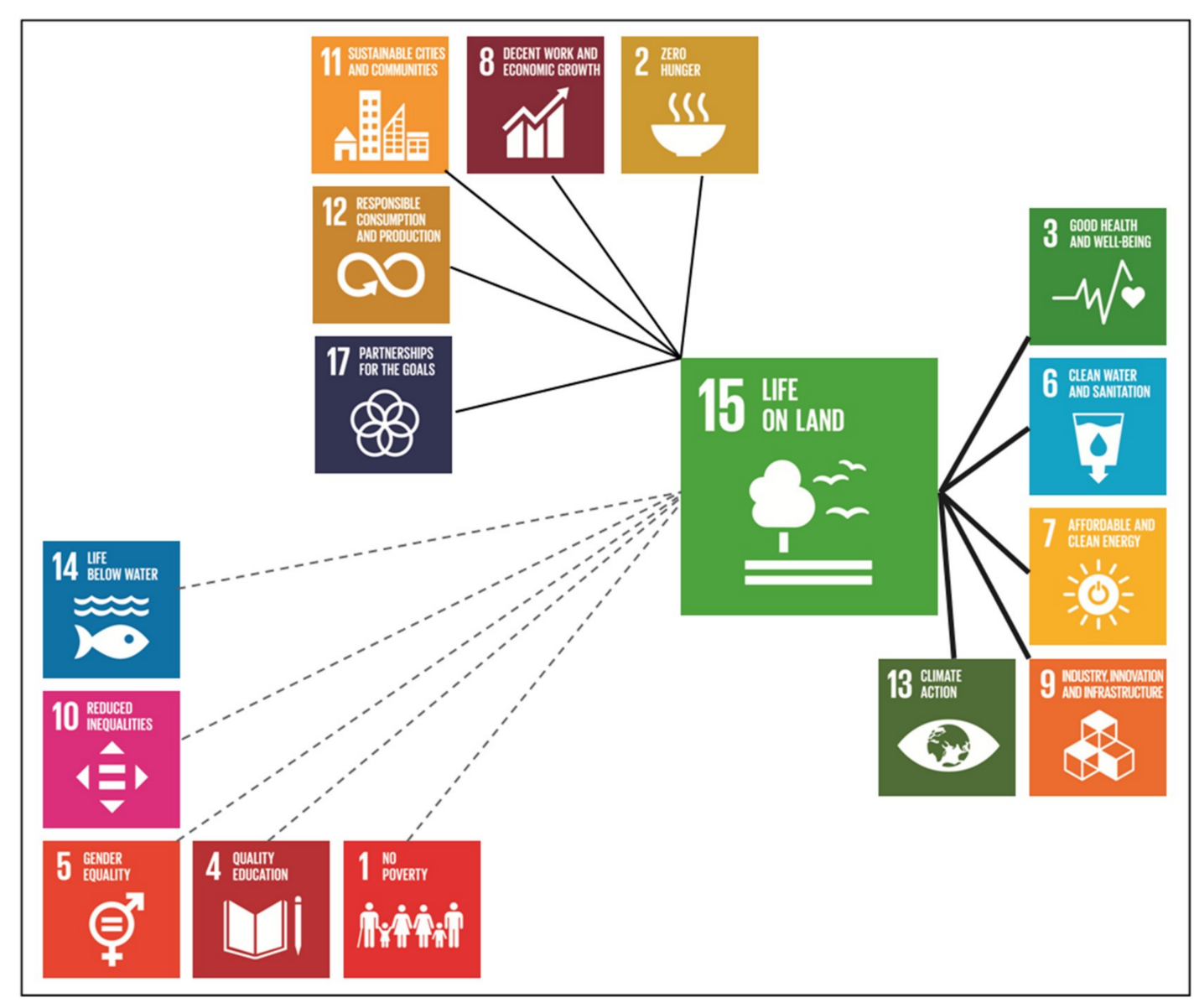

Figure 1. Interrelations between SDG15 (Life on Land) and other SDGs. The length and width of the lines relate to the apparent closeness of the SDGs with SDG15.

The "most important" SDG13 climate action has a direct bearing on forests. Therefore, according to the responses of SDG13, climate action is strongly connected to forests. In 2012, Austria was one of the first EU states to combine a strategic approach to climate change adaptation with a comprehensive action plan for the implementation of concrete recommendations for action which was revised and adopted in 2017. This new strategy was developed with a scientific approach and with evaluations from all stakeholder groups [28]. Therefore, as mentioned in the literature review, the perceptions corroborate showing that SDGs 3, 6, 7, are well connected to SDGs 13 and 15 (Tables 1 and 2).

"Very important" SDG9 (Innovation, infrastructure): This goal is observed as important for the forestry businesses in Austria. With timber production and tourism being two top revenue generators, the forestry business forms a big chunk of the Austrian economy. Even at policy levels, SDG9 imparts the importance of new innovations in the sustainable development of the forestry sector and greater business infrastructure. 
"Underrated" SDG17: Partnerships for the goals also find a moderate position on the strength of the linkage with SDG15, as according to some respondents, it is important but tends to get overlooked. It has the strongest connection with not only SDG15 but also to the rest of them. This is supposed to bridge the gaps between governments, the private sector, and civil society by sharing the development vision through the global goals [64].

"Short-term vision": Forests are long-lived communities. For well-managed forests, the ideal rotation period spans across decades. Therefore, decisions taken today will have consequences after a long period of time. So, the respondents observed that forestry targets under Goal 15 with tenure until 2030 involves a short term process whose success in the forestry sector will be difficult to assess.

"At times incomprehensible": Most of the respondents admitted, some explicitly and the rest indirectly, that although these 17 goals with well-endowed and thoughtfully designed targets are meant to meet global development processes, they run the danger of being too general and broad. The SDGs are set with scientific, social, and political consensus after a series of worldwide brainstorming efforts, but galvanizing them into proper action is a challenging task. Some of the respondents suggested that a more targeted approach would provide clearer guidance and make it easier to oversee the implementation of the goals. Also, coordination issues for this implementation are another crucial question as to who will come forward to coordinate. Also, with the different governance structures and different levels of development of different countries, these global goals undertaking the umbrella approach to sustainable development do not seem adequate. Evidently, the forestry element with the global SDG targets will not be similar for forests in different biomes or socio-political contexts. However, broadly, the SDGs touch upon every aspect of sustainable development without "leaving anyone behind".

"The emerging prospect of bio-economy in Austria.": The forest-based sector is one of Europe's biggest producers and users of bio-based energy. Traditional forest-based industries have evolved as great potential enablers for a future sustainable bio-economy [65]. However, the SDGs pose a purpose for governments to make additional demands on the different sectors like forestry, health, or business for developing new innovations in each of these sectors to progress towards the goals. According to the UN investment report of 2014 [66], to achieve the Global Goals by 2030, the estimated investment is approximately 5-7 trillion Euros a year. Since more than half the chunk of this investment is being expected from the private sector, there should be some gains for the private sector by implementing the SDGs. Therefore, there should be some incentivizing mechanism similar to corporate social responsibility (CSR) [67] through which any public or private sector business, organization, or institution implementing the SDGs should earn visibility and promotion so as to benefit from the implementation itself, besides business-as-usual. Therefore, along with "leaving no one behind", the SDG motto should also include "something for everybody" for it to be mainstream.

"Will I use the 2030 goals framework within my work in the recent future?" To this, "I do not know" and "it depends" is what most of the academics undertaking forest-related projects within Austria have to say. For them, there is still no clarity as to what value-addition could be received from incorporating the SDG framework into their project proposals for future projects. For forestry institutes, adequate funding for their work is one of the important criteria. Therefore, the SDG framework must provide some funding provisions under which projects will allocate additional funds for integrating this development framework into their activities. Otherwise, the SDGs have the danger of being just a "check-box" entity for a country-reporting exercise.

"No central role": Lastly, speaking on the role of SDGs in the overall Austrian forestry sector, the majority of the respondents expressed that until now the SDGs have had no role in the Austrian strategic development process, mainly in the forestry sector. However, it definitely has the potential for the future. Also, the demand for reporting the country-wide implementation-status of the SDG agenda at the international level might push for better implementation within certain sectors. 


\section{Conclusions}

The SDGs are commonly perceived as a dynamic agenda which requires a coherent, coordinated, and integrated approach. However, even after 4 years of its existence and innumerable dialogues, there has been little change in the implementation narrative of Agenda 2030 in Europe. Is this a matter of worry? Maybe for now, but not necessarily. The SDGs are found to be interlinked with the targets of the SFM in the European forestry sector. All these interlinked socio-economic, political, and environmental sectors must be approached in a balanced and synergistic way through strategic management and planning. Regarding forests in Austria, it is observed that none of the other SDGs hamper the attainment of the targets of SDG15. In fact, they complement, facilitate, and directly reinforce the other goals such as climate action, clean energy, water conservation, and much more.

Notably, the opinions of Austrian forestry stakeholders vary depending on the institutions, interest groups, and the political inclinations. However, some common trends exist since the majority of the stakeholders have concerns regarding the intentional broad scope of the SDGs, which was viewed as a challenge when evaluated for specific sectors. On the contrary, the SFM strategy was viewed as a mechanism that is based on thorough discussions of the pros and cons of the objectives and the tradeoffs between its targets. SFM is therefore currently more instrumental for the European forestry sector and as-of-now global agendas like the SDGs seem to be secondary for the already existing sustainability targets of a country like Austria which enjoy a legacy of SFM.

Reiterating the fact that for SFM to be implemented in practice, some of the components that need to come together are a broad-based commitment to comprehensive sustainability in forestry, including the protection and safeguarding of ownership rights and rights of use. In this aspect, Austria can always be an example for other countries under similar circumstances. Since the sustainability tradition is already well integrated into Austrian forestry sectors, awareness of the scope of the SDG framework can be helpful to some extent. Moreover, SDG is a tool which extends beyond forestry, and therefore, bridging the knowledge gaps can be advantageous to understand the linkages with other sectors. For the efficient implementation of the SDGs, a constant science/policy dialogue should be maintained. In addition, a sound legal framework and an effective institutional structure along with a well-balanced funding system should be in place. Also, mainstreaming the goals into the already ongoing government processes, the European Union and Austrian national policies with cross-scale policy coherence can serve as solutions to achieve the targets of Agenda 2030. The SDG Action Plan (2019-2022) being prepared by the Austrian Ministry of Sustainability and Tourism (BMNT) for release in 2019 could be a major initiative in this direction for mainstreaming the SDGs in the Austrian forestry sector.

Author Contributions: R.H. conceived the research idea, conducted interviews, analyzed perceptions, and wrote manuscript; R.J. edited the manuscript and suggested the study design.

Funding: This research received no funding.

Acknowledgments: We would like to thank The Ministry of Sustainability and Tourism (BMNT, Austria), The Federal Environment Agency, Austria, The Austrian Federal Chancellery (BKA), Österreichische Bundesforste (ÖBF), University of Natural Resources and Life Sciences (BOKU), Federal Environment Agency, GmBH, Austrian Research Centre for Forests(BFW), European Forest Institute, The European Forest Institute Central-East European Regional Office (EFICEEC), and International Union of Forest Research Organizations (IUFRO) European Sustainable Development Network (ESDN) for their inputs and suggestion.

Conflicts of Interest: The authors declare no conflict of interest. 


\section{Appendix A}

Table A1. SDG15 of the Agenda 2030 aims to protect, restore, and promote the sustainable use of terrestrial ecosystems, sustainably manage forests, combat desertification, and halt and reverse land degradation and halt biodiversity loss. This goal has 12 targets. Each target can be assessed by a set of indicators.

\begin{tabular}{l} 
Target \\
Target 15.1 \\
By 2020, ensure the conservation, restoration and sustainable use of \\
terrestrial and inland freshwater ecosystems and their services, in \\
particular forests, wetlands, mountains and drylands, in line with \\
obligations under international agreements \\
TARGET 15.2 \\
By 2020, promote the implementation of sustainable management of \\
all types of forests, halt deforestation, restore degraded forests and \\
substantially increase afforestation and reforestation globally \\
\hline TARGET 15.3 \\
By 2030, combat desertification, restore degraded land and soil, \\
including land affected by desertification, drought and floods, and \\
strive to achieve a land degradation-neutral world \\
\hline TARGET 15.4 \\
By 2030, ensure the conservation of mountain ecosystems, including \\
their biodiversity, in order to enhance their capacity to provide \\
benefits that are essential for sustainable development \\
TARGET 15.5 \\
Take urgent and significant action to reduce the degradation of \\
natural habitats, halt the loss of biodiversity and, by 2020, protect \\
and prevent the extinction of threatened species \\
TARGET 15.6 \\
Promote fair and equitable sharing of the benefits arising from the \\
utilization of genetic resources and promote appropriate access to \\
such resources, as internationally agreed \\
TARGET 15.7
\end{tabular}

\section{TARGET 15.7}

Take urgent action to end poaching and trafficking of protected species of flora and fauna and address both demand and supply of illegal wildlife products

\section{TARGET 15.8}

By 2020, introduce measures to prevent the introduction and significantly reduce the impact of invasive alien species on land and water ecosystems and control or eradicate the priority species

\section{TARGET 15.9}

By 2020, integrate ecosystem and biodiversity values into national and local planning, development processes, poverty reduction strategies and accounts

\section{TARGET 15.A}

Mobilize and significantly increase financial resources from all sources to conserve and sustainably use biodiversity and ecosystems

\section{TARGET 15.B}

Mobilize significant resources from all sources and at all levels to finance sustainable forest management and provide adequate incentives to developing countries to advance such management, including for conservation and reforestation

\section{TARGET 15.C}

Enhance global support for efforts to combat poaching and trafficking of protected species, including by increasing the capacity of local communities to pursue sustainable livelihood opportunities

\section{Indicator}

INDICATOR 15.1.1

Forest area as a proportion of total land area INDICATOR 15.1.2

Proportion of important sites for terrestrial and freshwater biodiversity that are covered by protected areas, by ecosystem type

\section{INDICATOR 15.2.1}

Progress towards sustainable forest management

\section{INDICATOR 15.3.1}

Proportion of land that is degraded over total land area

\section{INDICATOR 15.4.1}

Coverage by protected areas of important sites for mountain biodiversity

INDICATOR 15.4.2

Mountain Green Cover Index

INDICATOR 15.5.1

Red List Index

\section{INDICATOR 15.6.1}

Number of countries that have adopted legislative, administrative and policy frameworks to ensure fair and equitable sharing of benefits

\section{INDICATOR 15.7.1}

Proportion of traded wildlife that was poached or illicitly trafficked

\section{INDICATOR 15.8.1}

Proportion of countries adopting relevant national legislation and adequately resourcing the prevention or control of invasive alien species

\section{INDICATOR 15.9.1}

Progress towards national targets established in accordance with Aichi Biodiversity Target 2 of the Strategic Plan for Biodiversity 2011-2020

\section{INDICATOR 15.A.1}

Official development assistance and public expenditure on conservation and sustainable use of biodiversity and ecosystems

\section{INDICATOR 15.B.1}

Official development assistance and public expenditure on conservation and sustainable use of biodiversity and ecosystems

\section{INDICATOR 15.C.1}

Proportion of traded wildlife that was poached or illicitly trafficked

Source: United Nations, Sustainable Development Goals Knowledge Platform, available at https:// sustainabledevelopment.un.org/sdg15). 
Table A2. The questionnaire for personal interviews on analyzing the perceptions of sustainable forest management (SFM) and its alignment to the global goals among the key stakeholders from the Austrian forestry sector such as forestry institutions, policymakers, research institutes, and international NGOs.

\begin{tabular}{|c|c|}
\hline & Timestamp \\
\hline \multirow[t]{2}{*}{ Questions } & Full Name of Opinion leader \\
\hline & Affiliation (Office/Institution/Organization/Country) \\
\hline Q1 & $\begin{array}{l}\text { Which SDGs according to you have linkages with forests and how would describe these } \\
\text { linkages (weak and strong)? }\end{array}$ \\
\hline Q2 & $\begin{array}{l}\text { Which SDG out of the } 17 \text { is of key use for your work and which is the least or you think that } \\
\text { your work doesn't touch upon which SDG? }\end{array}$ \\
\hline Q3 & $\begin{array}{l}\text { SDGs are global in nature; therefore do you think the targets associated with each SDG should } \\
\text { be common everywhere or country-specific depending on the level of development? }\end{array}$ \\
\hline Q4 & $\begin{array}{l}\text { Do you think SDG15, gives sufficient guidance for adaptive/sustainable forest management in } \\
\text { Europe (specifically your country)? }\end{array}$ \\
\hline Q5 & Do you think you can/should incorporate it in your future projects? \\
\hline Q6 & Do you think SDGs are a political process? \\
\hline Q7 & $\begin{array}{l}\text { Although the main goal of the SDGs is to eradicate poverty but which goal do you think will } \\
\text { have more impact globally or be more successful by } 2030 \text { ? }\end{array}$ \\
\hline Q8 & $\begin{array}{l}\text { In your opinion what specific steps can be taken to ensure that the SDGs are coherent with and } \\
\text { integrated into the UN development agenda? }\end{array}$ \\
\hline \multirow[t]{5}{*}{ Q9 } & $\begin{array}{l}\text { Do you have any observations, ideas or inputs you would like to offer for the better working } \\
\text { of the SDGs? }\end{array}$ \\
\hline & (a) on awareness \\
\hline & (b) on implementation \\
\hline & (c) on design \\
\hline & (d) on institutional execution \\
\hline Q10 & Please briefly elaborate why do you think so (on Q9)? \\
\hline
\end{tabular}

\section{References and Note}

1. United Nations. About the Sustainable Development Goals, 2015. Available online: https://www.un.org/ sustainabledevelopment/sustainable-development-goals (accessed on 26 December 2018).

2. UNDP. Sustainable Development Goals, 2018. Available online: http://www.undp.org/content/undp/en/ home/sustainable-development-goals.html (accessed on 26 December 2018).

3. Le Blanc, D. Towards Integration at Last? The Sustainable Development Goals as a Network of Targets. Sustain. Dev. 2015, 23, 176-187. [CrossRef]

4. Rockström, J.; Steffen, W.; Noone, K.; Persson, A.; Chapin, F.S.; Lambin, E.F.; Lenton, T.M.; Scheffer, M.; Folke, C.; Schellnhuber, H.J.; et al. A safe operating space for humanity. Nature 2009, 461, 472-475. [CrossRef] [PubMed]

5. UNDP. Millenium Development Goals, 2015. Available online: http://www.undp.org/content/undp/en/ home/sdgoverview/mdg_goals.html (accessed on 26 December 2018).

6. Oliver, T.H.; Heard, M.S.; Isaac, N.J.B.; Roy, D.B.; Procter, D.; Eigenbrod, F.; Freckleton, R.; Hector, A.; Orme, C.D.L.; Petchey, O.L.; et al. Biodiversity and Resilience of Ecosystem Functions. Trends Ecol. Evol. 2015, 30, 673-684. [CrossRef] [PubMed]

7. Wolfslehner, B.; Linser, S.; Pülzl, H.; Bastrup-Birk, A.; Camia, A.; Marchetti, M. Forest Bioeconomy-A New Scope for Sustainability Indicators. From Science to Policy, European Forest Institute, 2016. Available online: https://www.efi.int/sites/default/files / files/publication-bank/2018/efi_fstp_4_2016 (accessed on 10 September 2018). 
8. Blattert, C.; Lemm, R.; Thees, O.; Lexar, M.J.; Hanewinkel, M. Management of ecosystem services in mountain forests: Review of indicators and value functions for model based multi-criteria decision analysis. Ecol. Indic. 2017, 79, 391-409. [CrossRef]

9. Costanza, R.; de Groot, R.; Braat, L.; Kubiszewski, I.; Fioramonti, L.; Paul Sutton, P.; Farber, S.; Grasso, M. Twenty years of ecosystem services: How far have we come and how far do we still need to go? Ecosyst. Serv. 2017, 28, 1-16. [CrossRef]

10. Hodge, D.; Brukas, V.; Giurca, A. Forests in a bioeconomy: Bridge, boundary or divide? Scand. J. For. Res. 2017, 32, 582-587. [CrossRef]

11. Bell, J.; Paula, L.; Dodd, T.; Németh, S.; Nanou, C.; Mega, V.; Campos, P. EU ambition to build the world's leading bioeconomy-Uncertain times demand innovative and sustainable solutions. Biotechnology 2018, 40, 25-30. [CrossRef] [PubMed]

12. Gratzer, G.; Keeton, W.S. Mountain Forests and Sustainable Development: The Potential for Achieving the United Nations' 2030 Agenda. Mt Res Dev. 2017. [CrossRef]

13. Perlin, J. A Forest Journey. In The Role of Wood in the Development of Civilization; Harvard Press: Harvard, MA, USA, 1991.

14. Kaplan, J.O.; Krumhardt, K.M.; Zimmermann, N. The prehistoric and preindustrial deforestation of Europe. Quat Sci Rev. 2009, 28, 3016-3034. [CrossRef]

15. Farrell, E.P.; Führer, E.; Ryan, D.; Andersson, F.; Hüttl, R.; Piussi, P. European forest ecosystems: building the future on the legacy of the past. For. Ecol. Manage. 2000, 132, 5-20. [CrossRef]

16. Schelhaas, M.J.; Fridman, J.; Hengeveld, G.M.; Henttonen, H.M.; Lehtonen, A.; Kies, U.; Krajnc, N.; Lerink, B.; Dhubháin, A.N.; Polley, H.; et al. Actual European forest management by region, tree species and owner based on 714,000 re-measured trees in national forest inventories. PLoS ONE 2018, 13, e0207151. [CrossRef] [PubMed]

17. Løyche Wilchie, M.; Holmgren, P.; Castaneda, F. Sustainable forest management and the ecosystem approach. In Working Paper FM 25; FAO: Rome, Italy, 2003.

18. Biber, P.; Borges, J.G.; Moshammer, R.; Barreiro, S.; Botequim, B.; Brodrechtová, Y.; Brukas, V.; Chirici, G.; Cordero-Debets, R.; Corrigan, E.; et al. How Sensitive Are Ecosystem Services in European Forest Landscapes to Silvicultural treatment? Forests 2015, 6, 1666-1695. [CrossRef]

19. SFM Guidelines. Forest Europe, 2016. Available online: https://foresteurope.org/sfm-guidelines (accessed on 26 December 2018).

20. Wolfslehner, B.; Vacik, H. Evaluating sustainable forest management strategies with the Analytic Network Process in a Pressure-State-Response framework. J. Environ Manage 2008, 88, 1-10. [CrossRef] [PubMed]

21. Colglazier, W. Sustainable development agenda: 2030. Science 2015, 349, 1048-1050. [CrossRef] [PubMed]

22. UNEP-WCMC and IUCN. Protected Planet Report 2016. How Protected Areas Contribute to Achieving Global Targets for Biodiversity; UNEP: Cambridge, UK; Gland, Switzerland, 2016; ISBN 978-92-807-3587-1.

23. Toscani, P.; Sekot, W. Assessing the Economic Situation of Small-Scale Farm Forestry in Mountain Regions: A Case Study in Austria. Mt Res. Dev. 2017, 37, 271-280. [CrossRef]

24. Fuso Nerini, F.; Tomei, J.; To, L.S.; Bisaga, I.; Parikh, P.; Black, M.; Borrion, A.; Spataru, C.; Castan-Broto, V.; Anandarajah, G.; et al. Mapping synergies and trade-offs between energy and the Sustainable Development Goals. Nat. Energy 2018. [CrossRef]

25. Körfgen, A.; Förster, K.; Glatz, I.; Maier, S.; Becsi, B.; Meyer, A.; Kromp-Kolb, H.; Stötter, J. It's a Hit! Mapping Austrian research contributions to the sustainable development goals. Sustainability 2018. [CrossRef]

26. Bryman, A. Social Research Methods, 4th ed.; Oxford University Press: Oxford, UK, 2012.

27. Mikkelsen, B. Methods for development work and research. In A New Guide for Practitioners, 2nd ed.; SAGE Publications: Thousand Oaks, CA, USA, 2005.

28. Blumer, H. Symbolic Interactionism: Perspective and Method. The Methodological Positioning of Symbolic Interactionism; University of California Press: California State University, CA, USA, 1986; pp. 1-61.

29. Forests in Austria, BFW (Austrian Research Centre for Forests). 2017. Available online: https://bfw.ac.at/ rz/bfwcms.web?dok=10282 (accessed on 26 December 2018).

30. Deinhardsetein, A.F.; Piribauer, V.C.; Prem, J. (Eds.) Sustainable Forest Management in Austria. Austrian Forest Report 2015. Federal Ministry of Agriculture Forestry Environment and Water Management, 2015. Available online: www.bmlfuw.gv.at (accessed on 26 December 2018). 
31. Austrian Strategy for Adaptation to Climate Change. BMNT, Communication 2018. Available online: https:/ / www.bmnt.gv.at/english/environment/Climateprotect/Austrian-Strategy-for-Adaptation-toClimate-Change.html (accessed on 26 December 2018).

32. Austrian Forest Programme. BMLFUW, Wald-Dialogue 2007. Available online: https://bildung. bmbwf.gv.at/schulen/euint/eubildung_abb2010/abb2010_zwb07_en_15321.pdf?68yv1n (accessed on 26 December 2018).

33. Exportinitiative Forst und Holz. Wald in Österreich. 2005. Available online: http://www.wald-inoesterreich.at/exportinitiative-forst-und-holz (accessed on 26 December 2018).

34. Lindner, M.; Maroschek, M.; Netherer, S.; Kremer, A.; Barbati, A.; Garcia-Gonzalo, J.; Seidl, R.; Delzon, S.; Corona, P.; Kolstrom, M.; et al. Climate change impacts, adaptive capacity, and vulnerability of European forest ecosystems. For. Ecol. Manage 2010, 259, 698-709. [CrossRef]

35. Seidl, R.; Rammer, W.; Lexer, M.J. Climate change vulnerability of sustainable forest management in the Eastern Alps. Clim Change 2011, 106, 225-254. [CrossRef]

36. Brang, P.; Breznikar, A.; Hanewinkel, M.; Jandl, R.; Maier, B. Managing Alpine Forests in a Changing Climate. Intech 2013, 369-383. [CrossRef]

37. Thom, D.; Seidl, R.; Steyrer, G.; Krehan, H. Slow and fast drivers of the natural disturbance regime in Central European forest ecosystems. For. Ecol. Manag. 2013, 307, 293-302. [CrossRef]

38. Bolte, A.; Ammer, C.; Löf, M. Adaptive forest management in central Europe: Climate change impacts, strategies and integrative concept. Scand. J. For. Res. 2009, 24, 473-482. [CrossRef]

39. Forest Europe, 2011 State of Europe's Forest. 2011. Available online: https://www.foresteurope. org/documentos/State_of_Europes_Forests_2011_Report_Revised_November_2011.pdf (accessed on 26 December 2018).

40. The Dynamics of the Strasbourg and Helsinki Process, The European Parliament, Europe and the Forests, Volume 3. Chapter 1.4, The Future Forests and the Strategies for the European Union. 1993. Available online: http:/ / www.europarl.europa.eu/workingpapers/forest/eurfo137_en.htm (accessed on 26 December 2018).

41. Ministerial Conference for the Protection of Forests in Europe 18 December 1990, Strasbourg/France. RESOLUTION S4 Adapting the Management of Mountain Forests to New Environmental Conditions. Available online: https://www.foresteurope.org/docs/MC/strasbourg_resolution_s4.pdf (accessed on 30 January 2019).

42. Austrian Forest Act. Bundesgesetz vom 3. Juli 1975, mit dem das Forstwesen geregelt wird (Forstgesetz 1975) StF: BGBl. Nr. 440/1975 (NR: GP XIII RV 1266 AB 1677 S. 150. BR: 1392 AB 1425 S. 344.) (accessed on 10 September 2018).

43. The Alpine Convention 1991. Available online: http://www.alpconv.org/en/convention/history/pages/ default.aspx?AspxAutoDetectCookieSupport=1 (accessed on 26 December 2018).

44. Vision 2040 of the European Forest Based Sector, Technology Platform 2018. Available online: http: / /www.forestplatform.org/system/attachments/files/000/000/578/original/ForestBasedVision2040-Brochure-V9_final.pdf?1542701377 (accessed on 26 December 2018).

45. Keeping an Eye on SDG15, Working with Countries to Measure Indicators for Forests and Mountains. 2013. Available online: http:/ / www.fao.org/3/a-i7334e.pdf (accessed on 26 December 2018).

46. SDG Indicators, Department of Economics and Social Affairs, Metadata Repository, 2018. Available online: https:/ / unstats.un.org/sdgs/metadata/?Text\&Goal=15\&Target (accessed on 26 December 2018).

47. Global Sustainable Development Report 2016, Department of Economic and Social Affairs, New York, July. United Nations, 2016. Available online: https://www.un.org/development/desa/publications/globalsustainable-development-report-2016.html (accessed on 26 December 2018).

48. SDG Knowledge Platform. SDG15. 2018. Available online: https://sustainabledevelopment.un.org/sdg15 (accessed on 26 December 2018).

49. SDG Knowledge Platform. SDG4. 2018. Available online: https://sustainabledevelopment.un.org/sdg4 (accessed on 26 December 2018).

50. Briner, S.; Huber, R.; Bebi, P.; Elkin, C.; Schmatz, D.R.; Grêt-Regamey, A. Trade-offs between ecosystem services in a mountain region. Ecol. Soc. 2013. [CrossRef] 
51. Lange, B.; Losey, S.; Sandri, A. Protection Forests in Switzerland: from Delimitation to Management Mountain Watersheds and Ecosystem Services: Balancing multiple demands of forest management in Mountain Watersheds and Ecosystem Services: Balancing. Int. J. Water Resour. Dev. 2017, 33, 138-148. [CrossRef]

52. Searchinger, T.D.; Wirsenius, S.; Beringer, T.; Dumas, P. Assessing the efficiency of changes in land use for mitigating climate change. Nature 2018, 564, 249-253. [CrossRef] [PubMed]

53. Klima- und Energiefonds. Factcheck Energywende 2016-2017. Fakten statt Mythen zur Zukunft der Energieversorgung. 2017. Available online: https://faktencheck-energiewende.at/wp-content/uploads/ sites/4/Faktencheck_2016.pdf (accessed on 26 January 2019).

54. Viktor, J.; Bruckman, V.J.; Alexander, E.; Helmisaari, H.S.; Stupakd, I.; Titus, B. KIOES Guidelines for Sustainable Forest Biomass Production-Challenges in View of an Emerging Bioeconomy. 2018. Available online: https:/ / www.oeaw.ac.at/kioes/kioes/detail/article/guidelines-for-sustainable-forestbiomass-production-challenges-in-view-of-an-emerging-bioeconomy/ (accessed on 26 December 2018).

55. A Europe to Thrive in-Environment, Health and Well-Being EEA, 2015. Available online: https://www. eea.europa.eu/articles/a-europe-to-thrive-in (accessed on 26 December 2018).

56. Forests And Sustainable Cities In Europe: Contribution of Forests and SFM to Sustainable Living and Well-Being in European Cities, FOREST EUROPE Side Event 13th Session of the United Nations Forum on Forests. 2017. Available online: https:/ / foresteurope.org/wp-content/uploads/2017/08/UNFF_13_ver3_ 0.pdf (accessed on 26 December 2018).

57. Kroll, C. With a Foreword by Kofi Annan, Sustainable Development Goals: Are the Rich Countries Ready? OECD (2013). Environmental Performance Review: Austria. 2013. Available online: http:/ / www.keepeek.com/Digital-Asset-Management/oecd/environment/oecd-environmentalperformance-reviews-austria-2013_9789264202924-en\#page1 (accessed on 26 December 2018).

58. Nilsson, M.; Griggs, D.; Visbeck, M. Map the interactions between Sustainable Development Goals. Nature 2016, 534, 321. [CrossRef] [PubMed]

59. Austrian Market Report 2017. Statement submitted by the Austrian Delegation to the Joint Session of the ECE Committee on Forests and the Forest Industry (75th session) and the FAO European Forestry Commission (39th session) Warsaw, 9-13 October 2017. Available online: ww.unece.org/fileadmin/DAM/ timber/country-info/statements/austria2017.pdf (accessed on 26 December 2018).

60. Forest Management is Sustainable in Austria. Austria's Forest Policy Pursues the Principle of Sustainable Forest Management. 2017. Available online: https:/ / www.bmnt.gv.at/english/forestry/Austriasforests/ Forestmanagement.html (accessed on 30 January 2019).

61. Weiss, G.; Pettenella, D.; Ollonqvist, P.; Slee, B. Innovation in Forestry: Territorial and Value Chain Relationship. CABI 2011, 63, 331. [CrossRef]

62. Seidl, R.; Albreich, K.; Thom, D.; Rammer, W. Harnessing landscape heterogeneity for managing future disturbance risks in forest ecosystems. J. Environ. Manag. 2018, 209, 46-56.

63. Ecosoc Partnership Forum Breaking the Silos: Cross-Sectoral Partnerships for Advancing the Sustainable Development Goals (SDGs), 2016. Available online: https://www.un.org/ecosoc/sites/www.un.org.ecosoc/ files/files/en/2016doc/partnership-forum-issue-note1.pdf (accessed on 26 December 2018).

64. UNSD. 2018 Goal 17: Revitalize the Global Partnership for Sustainable Development, 2018. Available online: https:/ / www.un.org/sustainabledevelopment/globalpartnerships / (accessed on 26 December 2018).

65. Horizons-Vision 2030 for the European Forest-Based Sector 2013. Available online: http://www.cepi.org/ system/files/public/documents / publications / forest/2013/FTP_Vision_final_Feb_2013pdf (accessed on 26 December 2018).

66. UN World Investment Report Investing in the SDGs: An Action Plan, 2014. Available online: https: / / unctad.org/en/PublicationsLibrary/wir2014_en.pdf (accessed on 26 December 2018).

67. Fontaine, M. Corporate Social Responsibility and Sustainability: The New Bottom Line? Int. J. Bus. Soc. Sci. 2013, 4, 110 .

(C) 2019 by the authors. Licensee MDPI, Basel, Switzerland. This article is an open access article distributed under the terms and conditions of the Creative Commons Attribution (CC BY) license (http:/ / creativecommons.org/licenses/by/4.0/). 